\title{
Anaerobic digestion of mixed dried fallen leaves by mixing with cow dung
}

\author{
M. A. Rouf $^{1 *}$, M. S. Islam ${ }^{1}$, T. Rabeya ${ }^{1}$, A. K. Mondal $^{1}$ \\ ${ }^{1}$ Institute of Fuel Research and Development, Bangladesh Council of Scientific and Industrial Research, Dhanmondi, \\ Dhaka-1205, Bangladesh.
}

\begin{abstract}
An investigation was carried out for the production of biogas from dry fallen leaves. The sample was collected from BCSIR campus of Dhaka in winter. The substrate was mixed leaves mainly mahogany (75\%), eucalyptus (10\%) and rain tree (15\%) leaves. The study was carried out by whole leaves and crushed leaves directly followed by aerobic pretreatment at $8 \%$ total solid (TS) concentration. The raw materials were fed into two liter capacity glass bottle bio digester on batch basis for 60 days at ambient temperature. Different proportion of substrate and cow dung were mixed to get the optimum mix for maximum yield of biogas. The biogas reactor containing $6 \%$ crushed and pretreated leaves mixed with $2 \%$ cow dung (on $8 \%$ TS basis) gave maximum $(0.199 \mathrm{l} / \mathrm{g}$ ) biogas yield. The biogas yield from leaves without pretreatment was found to be too low $(0.0106 \mathrm{l} / \mathrm{g})$ for $8 \%$. The COD reduction, VS reduction and methane composition of two biogas reactors have been determined where biogas yield were relatively higher. The maximum methane content of the biogas was found to be about $69.3 \%$.
\end{abstract}

Keywords: Anaerobic digestion; Biogas; Volatile solids (VS); COD reduction; Pretreatment

\section{Introduction}

The demand for energy is increasing day by day with the rapid increase of population but the fossil fuel reserve is decreasing continuously. To overcome the energy crisis, alternative energy sources are the only suitable means for eco friendly remedy. Generation of energy from waste is beneficial in many ways. Biogas generation from waste biomass is the most suitable technique for waste disposal/management and sustainable development. In the recent times, biogas technology has been considered as a good source of employment creating facilities especially in third world countries. It is important to assess the potential of biogas generation from fallen dried leaves as resource from deciduous forest as local biomass. In winter season huge quantities of fallen dried leaves generated from hilly areas of Bangladesh like Chittagong hill tracts, Rangamati hill forest, Sylhet hill forest and shal forest of Gazipur Mymensingh, Tangail etc. and even in the homestead garden considerable amount of dried leaves are generated. Fallen dried leaves readily available in the forest areas of Bangladesh. The leaves sometimes constitute a nuisance in the environment as a waste. For this reason in hilly areas, these leaves are burned off which is harmful for environment, because open burning of leaves produce harmful toxic gases and also increase greenhouse gases. But if biogas is produced from the leaves, greenhouse gas emission reduction is possible in one hand and on the other hand, clean fuel gas as well as nutrient rich organic fertilizer is produced. Characterization of press mud from sugar industry and its potential for biogas generation has been done by Rouf et al., (1999). Generally, the production of this gas involves a complex biochemical reaction that takes place under anaerobic conditions in the presence of highly $\mathrm{pH}$ sensitive bacteria. The $\mathrm{pH}$ range is 6.5-8.0 (Rahman and Muyeed, 2010). Three important nutrient polymers such as carbohydrates, proteins and lipids are required for the reaction to take place and these are broken down by the anaerobes in a 3-stage digestion process namely hydrolysis, acidogenesis / acetogenesis and methanogenesis. The major products of this reaction are methane $\left(\mathrm{CH}_{4}\right)$ and carbon dioxide $\left(\mathrm{CO}_{2}\right)$ (Hashimoto et al., 1980). Other gases found in trace levels from the reaction are $\mathrm{H}_{2} \mathrm{~S}, \mathrm{CO}, \mathrm{NH}_{3}, \mathrm{~N}_{2}, \mathrm{H}_{2}$ and water vapour. The levels of these gases depend on the nature of the waste (Uzodinma et al., 2007). Animal wastes that have been utilized for biogas production include cattle of different types (Nwagbo et al., 1991; Garba et al., 1996; Zuru et al., 1998; Itodo and Kucha, 1998). Crop residues have been utilized for biogas production. These include: rice husk (Eze, 1995; Uzodinma et al., 2007), grass from different species (Mahnert et al., 
2005) and other terrestrial plant wastes (Lucas and Bamgboye, 1998). The main components in plant origin biomass are cellulose and hemicelluloses, lignin etc. Hemicelluloses and lignin are difficult to digest by bacteria. In order to let the bacteria get more digestible foods, the hemicelluloses and lignin must broken down (Kozo et al., 1996; Fulford, 1998). The wood-decaying white rot fungi degrade lingo-cellulose substrate by lignolytic enzymes such as lignin peroxidase, manganese peroxidase, and laccase in the first step of the degradation process; in this way, they demonstrate their ability to oxidize lignin into simple organic compounds. On the other hand, released cellulose and hemicelluloses are decayed by cellulolytic enzymes in the next step (Uzodinma et al., 2007). A few research work has been studied for generation of biogas from leaves in abroad such as (Tomáš et al., 2012) studied increase of biogas production from pretreated hay and leaves using wood-rotting fungi; (Geol et al., 2001) studied two-phase anaerobic digestion of spent tea leaves for biogas and manure generation; Birnin-Yauri (2013) studied bio-methane generation from the leaves and stems of Ricinus communis under anaerobic condition. Although attempts have been made by scientists for generation of biogas from different lingocellulosic plant material but very few research has been done for anaerobic digestion of leaves. Not much scientific data are available for biogas generation from plant leaves. In Bangladesh plenty of leaves are available in different parts of the country but any scientific research has yet to be done. In this context, the research project has been undertaken.

The objectives of the research work are to characterize the substrate, optimize the biogas generation and study the biogas composition, to examine the performance of biogas unit set up by using leaves.

\section{Materials and methods}

\section{Collection of sample and pretreatment methods}

The dried leaves sample was collected from BCSIR campus of Dhaka in winter. The substrate was mixed leaves mainly mahogany $(75 \%)$, eucalyptus $(10 \%)$ and rain tree $(15 \%)$ leaves. The sample was grounded by a grinder. Both the whole leaves and grounded leaves were pretreated in aerobic condition for 10 days by adding effluent from stable biogas digester.

Analysis of sample

Moisture content and ash content were estimated by gravimetric method by drying at $105^{\circ} \mathrm{C}$ and by complete combustion at $800^{\circ} \mathrm{C}$. Calorific value was determined according to IS: 1350 (part 4) 197 by bomb calorimeter. Total solids (TS) were estimated by subtracting the moisture content from $100 \%$ and volatile solids (VS) were estimated according to the procedure recommended in IS: 10158-1982 by heating at $600^{\circ} \mathrm{C}$ for two hours in a furnace. Carbon and nitrogen contents in the sample were determined with the help of a C-N-H-S analyzer (Thermo Fischer Scientific, FLASH-2000) with TCD detector. Helium gas was used as carrier gas at $250 \mathrm{kPa}$ and $140 \mathrm{ml} / \mathrm{min}$, furnace and oven temperatures were $900^{\circ} \mathrm{C}$ and $65^{\circ} \mathrm{C}$ respectively. Chemical oxygen demand (COD) of the sample was estimated by oxidizing the sample with potassium dichromate then titrating with ferrous ammonium sulphate using ferroin indicator (APHA, 1992). $\mathrm{pH}$ of the sample slurry was recorded using digital $\mathrm{pH}$ meter (HANNA,HI 98208) and gas composition was determined by gas chromatograph (Thermo Fischer Scientific, Trace GC Ultra with TCD detector). Helium gas was used as carrier gas at $900 \mathrm{kPa}$ and 10.5 $\mathrm{ml} / \mathrm{min}$, Oven and detector temperatures were $80^{\circ} \mathrm{C}$ and $180^{\circ}$ $\mathrm{C}$ respectively.

\section{Experimental set up for anaerobic digestion in the laboratory}

The sample was fed into two liter capacity wide mouthed glass bottle on batch basis for 60 days at ambient temperature. Volume of the substrate in the glass bottle was one liter. It was inoculated (10\% inoculums) with the sludge collected from an anaerobic plant based on cow dung. Seven anaerobic reactors were set up containing different proportion of substrate and cow dung on the basis of $8 \%$ TS. The total gas production was measured by water displacement method at an interval of 24 hours. Contents of the bottle were mixed manually after every gas measurement. Daily gas production was recorded. The conditions of the seven biogas reactors were as follows:

Reactor1 (R1): $8 \%$ whole leaves without cow dung Reactor 2 (R2): $6 \%$ whole leaves $+2 \%$ cow dung Reactor 3 (R3): 4\% whole leaves $+4 \%$ cow dung Reactor 4 (R4): $8 \%$ pretreated whole leaves without cow dung

Reactor 5 (R5): 8\% pretreated ground leaves without cow dung

Reactor 6 (R6): $6 \%$ ground pretreated leaves $+2 \%$ cow dung Reactor 7 (R7): $4 \%$ pretreated ground leaves $+4 \%$ cow dung

\section{Results and discussion}

Characteristics of the sample are given in Table. I. The $\mathrm{pH}$ of $8 \%$ sample slurry was found to be 7.05 which is in the range of optimum $\mathrm{pH}$ as observed by Rahman and Muyeed (2010). TS was found to be $88.14 \%$, VS was found to be $86 \%$ on dry matter basis, COD of $10 \%$ slurry was found to be $70.40 \mathrm{~g} / 1$ and $\mathrm{C} / \mathrm{N}$ ratio of the substrate was found to be $40: 1$ which is higher than optimum $\mathrm{C} / \mathrm{N}$ ratio for biogas generation (20:1 to $30: 1$ ) 
(Rahman and Muyeed, 2010). COD value of 10\% sample slurry was found to be $70.40 \mathrm{~g} / \mathrm{l}$ and calorific value of the leaves sample was found to be $3384.82 \mathrm{kcal} / \mathrm{kg}$.

Table I. Characteristics of leaves sample collected from BCSIR campus Dhaka

\begin{tabular}{ll}
\hline Test parameter & Value \\
\hline pH (8\% TS) & 7.05 \\
TS (\%) & 88.14 \\
VS (\%) & 86.00 \\
Moisture content $(\%)$ & 11.85 \\
COD $(\mathrm{g} / \mathrm{l})$ of $10 \% \mathrm{sample}$ & 70.40 \\
Calorific value $(\mathrm{kcal} / \mathrm{kg})$ & 3384.82 \\
$\mathrm{C} / \mathrm{N}$ ratio & 40 \\
\hline
\end{tabular}

Daily gas production

Fig. 1 to Fig. 7 represents the daily gas production in seven reactors. It shows a belt shape trend. It was observed that gas

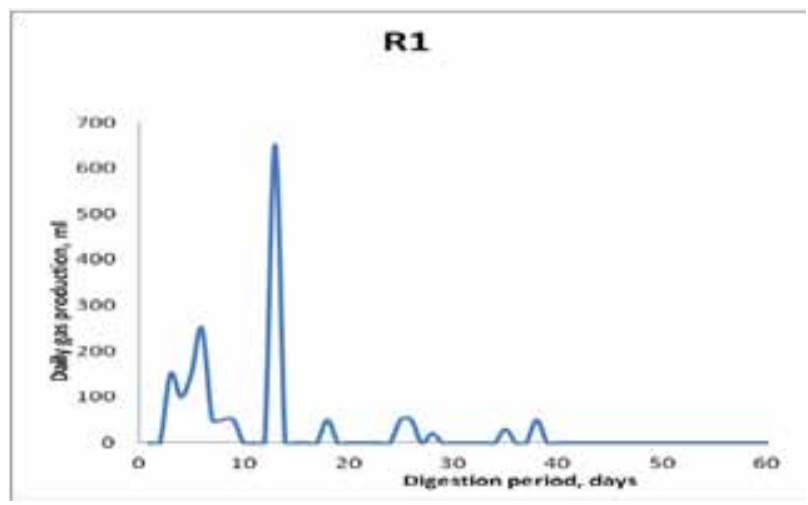

Fig. 1. Daily gas production in reactor R1

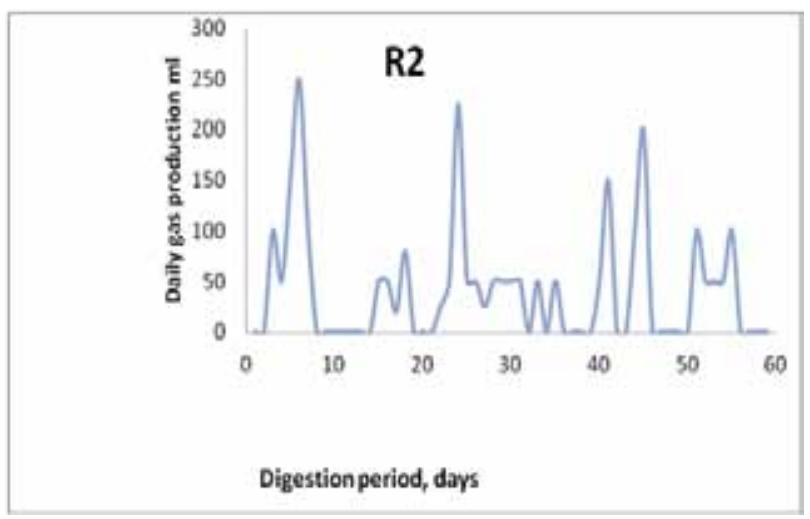

Fig. 2. Daily gas production in reactor $\mathbf{R} 2$

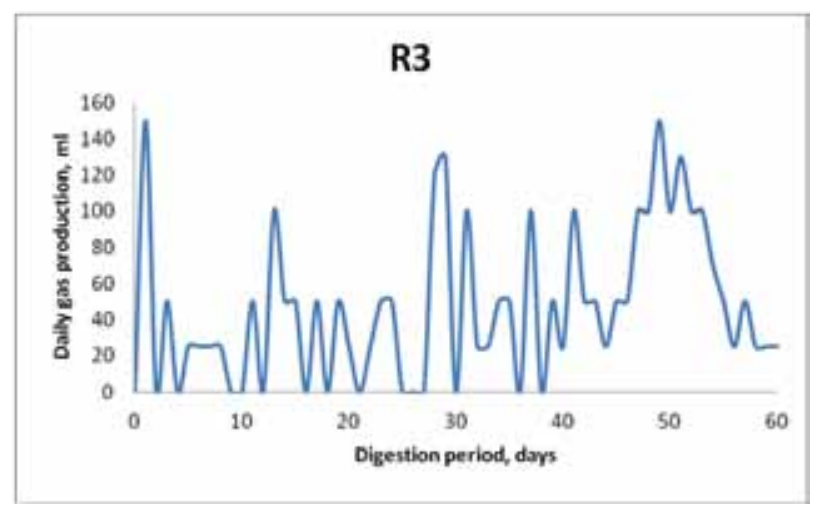

Fig. 3. Daily gas production in reactor $\mathbf{R} 3$

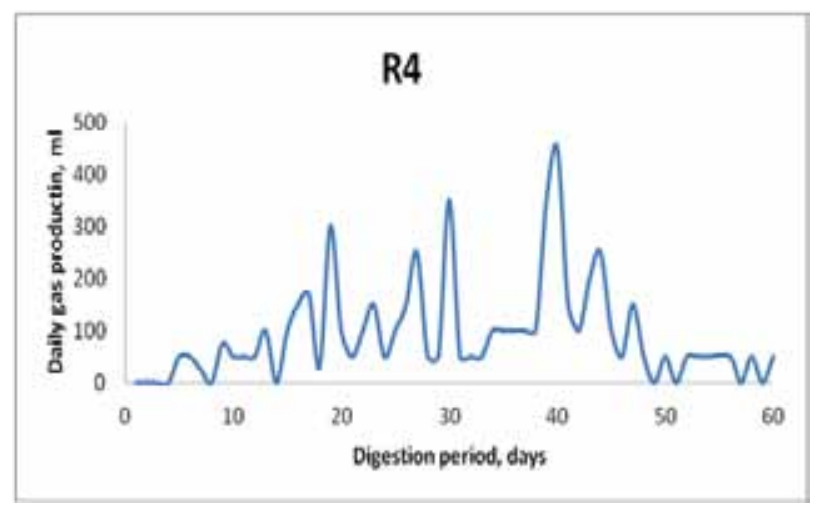

Fig. 4. Daily gas production in reactor $\mathrm{R} 4$

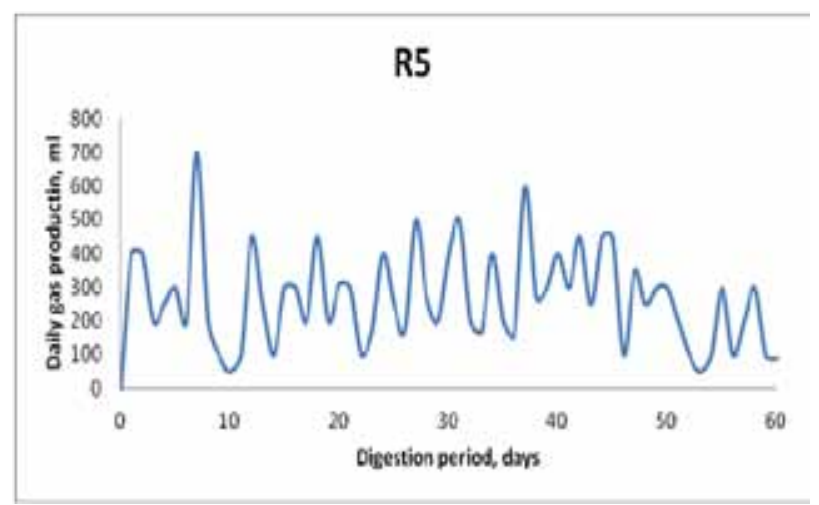

Fig. 5. Daily gas production in reactor $\mathrm{R5}$

production started at the very next day of charging the digesters with the substrate slurry. The rate of gas generation gradually increased with increasing digestion period. The graph also indicates that during the digestion period, most of the daily gas production range was between $150 \mathrm{ml}$ and $400 \mathrm{ml}$. But in R6 and R7, highest amount of daily gas $(600 \mathrm{ml}$ and $700 \mathrm{ml}$ respectively) was produced in $14^{\text {th }}$ day and $7^{\text {th }}$ day respectively. 


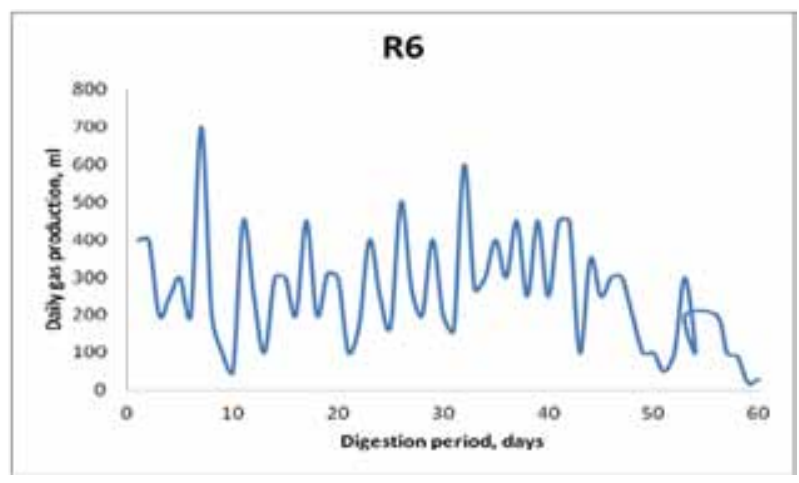

Fig. 6. Daily gas production in reactor $\mathrm{R} 6$

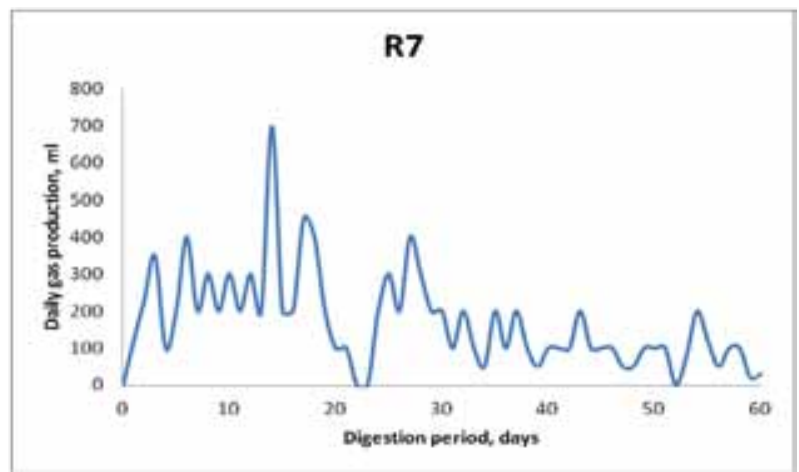

Fig. 7. Daily gas production in reactor $\mathbf{R} 7$

\section{Cumulative gas production}

Cumulative gas production in seven reactors are shown in Fig. 8. Due to crushing of leaves the particle size decreased many times and surface area was increased. As a result gas production was increased 10 times than uncrushed leaves .It was observed that lag phase prevailed up to 5-6 days of digestion period. This is due to microbe limiting at the initial stage of fermentation. After the lag period, the cumulative volume of gas increased up to 42 to 45 days of (except R1and R2) fermentation period after which the rate of generation decreased and this declination continues until gas generation almost decreased. At the end of sixty days of digestion period, gas generation in all the reactors were almost ceased. Fig. 9. represents the variation of cumulative gas production in seven reactors in every 10 days interval. The figs. show that in R6 and R7 gas production was highest in $4^{\text {th }}$ ten days and $2^{\text {nd }}$ ten days respectively. The fig. also shows that highest amount of gas was generated from R6 (where cow dung concentration was too low 2\%) than R7 (where cow dung concentration was double i, e. 4\%). Since biogas yield is relatively higher in R6 and R7 compared to other five reactors, these two reactors were taken for further study of $\mathrm{pH}$ effect, VS destruction, COD reduction etc.

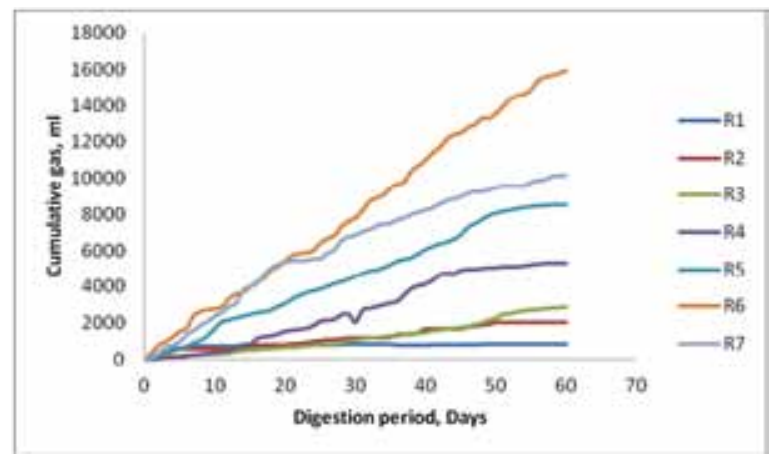

Fig. 8. Cumulative gas production in seven reactors

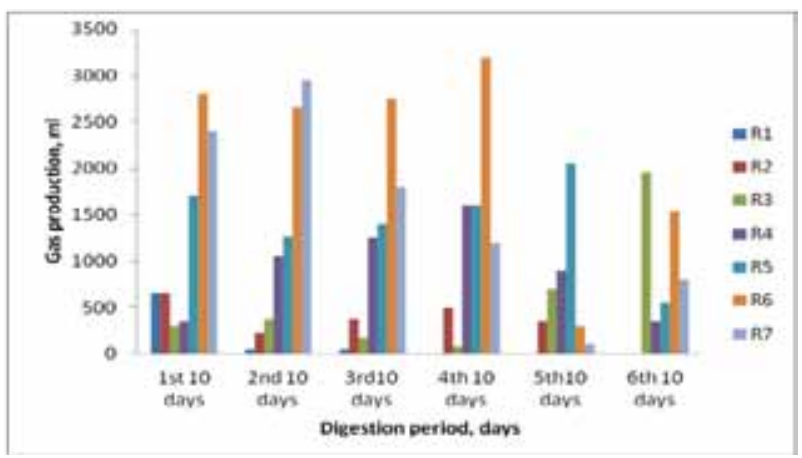

Fig. 9. Variations of gas production in seven reactors in every 10 days

\section{VS destruction in batch reactor}

Biogas generation is specially related to reduction of biodegradable fraction of VS in the digester. VS reduction trend curves in the biogas reactor R6 and R7 are shown in Fig. 10. The concentration of VS in the slurry was decreased with increasing digestion period. VS reduction in the test reactors was observed in the range of $35.33 \%$ and $34 \%$ in R6 and R7 respectively. These values are comparable with the VS reductions reported in the literature for various substrates (Rouf et al., 2010; Thangamani et al., 2009).

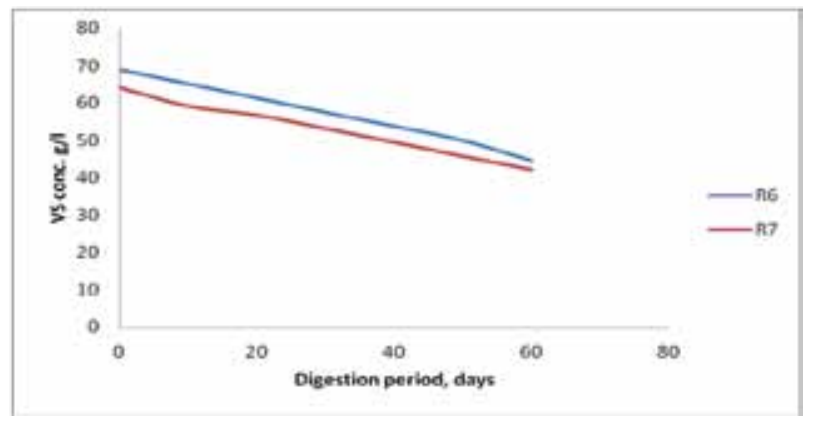

Fig. 10. Trend curve of VS destruction in reactors R6 and R7 


\section{COD value reduction}

The reduction of COD value means the reduction of pollution load from any substrate by treatment method. COD of the slurry considerably reduced by anaerobic process. Fig. 11. shows the trend of COD value reduction curve. Percentage of COD reduction was achieved $34.89 \%$ in $\mathrm{R} 6$ and $33.90 \%$ in R7. The trend line shows that good correlation exists between digestion time and COD value as the $\mathrm{R}^{2}$ value is above $99 \%$ for both the two reactors.

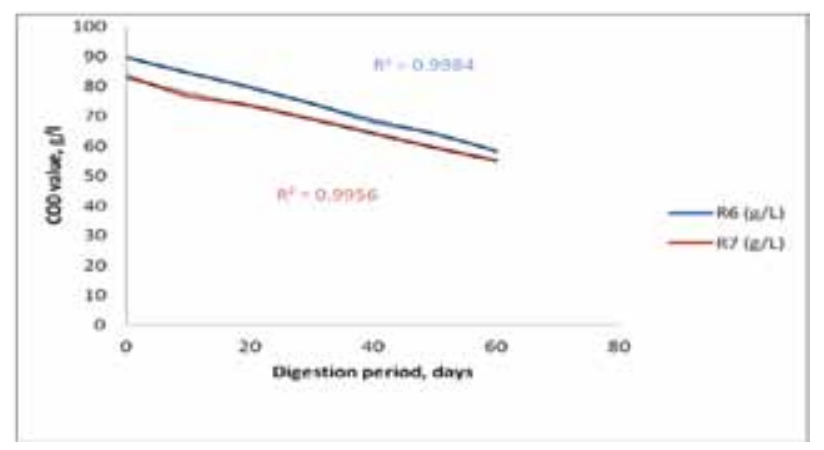

Fig. 11. Trend curve of COD reduction in reactors $R 6$ and $R 7$

\section{Effect of $p H$}

$\mathrm{pH}$ is an important factor for anaerobic digestion process. Fig. 12 represents the effect of $\mathrm{pH}$ for biogas generation from leaves. Both the figs. show that initially, $\mathrm{pH}$ level of the slurry

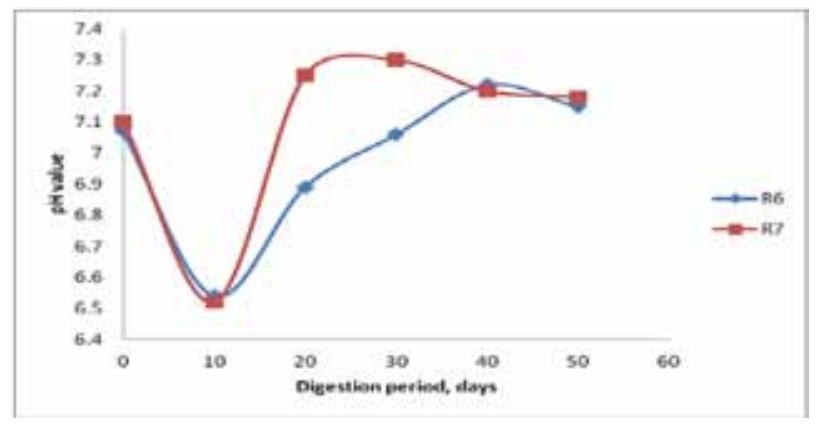

Fig. 12. $\mathrm{pH}$ profile in reactors $\mathrm{R} 6$ and $\mathrm{R} 7$

was decreased. Because acid forming bacteria acts very quickly and forms volatile acids like acetic acid, propionic acid, butyric acid, iso-valeric acid, etc. As a result $\mathrm{pH}$ falls down. With the increase of digestion period, $\mathrm{pH}$ again increased because of the methanogenic bacterial action and thus the volatile acids converted into methane and carbon dioxide.

\section{Gas composition}

Fig. 13 shows the gas composition in reactor R6 and R7. In the first ten days of digestion period, methane percentage is

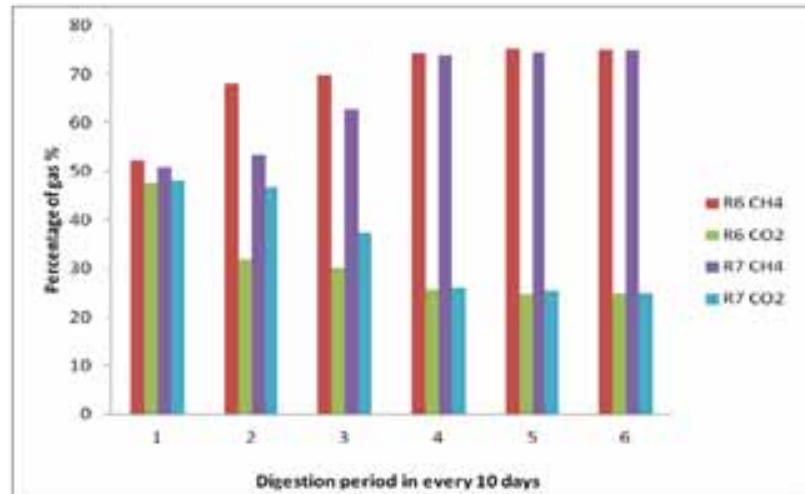

Fig. 13. Gas composition in reactors $R 6$ and $R 7$

lower than carbon dioxide in both the reactors. The reason is that initially long chain polymeric molecules were converted to smaller chain molecules and then converted to different volatile acids. During this process some $\mathrm{CO}_{2}$ was produced. In addition to this, the $\mathrm{CO}_{2}$ from degradation of acetate to methane also added to the produced gas and increased the percentage of $\mathrm{CO}_{2}$ in the gas composition. After 20 days of digestion period, $\mathrm{CH}_{4}$ content was increased considerably and it was continued until gas generation stopped. $\mathrm{CH}_{4}$ content was almost similar $(69.3 \%)$ in both the reactors.

Table II shows the comparative study of reactor R6 and reactor R7. From the comparative study it is found that both biogas yield and methane composition were higher in reactor R6 and VS reduction as well as COD reduction were also higher in reactor R6.

Table II. Comparative study of reactor $\mathrm{R} 6$ and reactor $\mathrm{R} 7$

\begin{tabular}{lcc}
\hline \multicolumn{1}{c}{ Sl. No. } & Reactor R6 & Reactor R7 \\
\hline Biogas yield (1/g) & 0.199 & 0.156 \\
Methane composition (\%) & 69.3 & 68.2 \\
VS reduction (\%) & 35.33 & 34 \\
COD reduction (\%) & 34.89 & 33.90 \\
\hline
\end{tabular}

\section{Conclusions}

The organic content of the sample is very high (about $88 \%$ volatile solids), which are biodegradable. But the $\mathrm{C} / \mathrm{N}$ ratio of the sample is much higher (40:1). So mixing of cow dung with the substrate is very important to achieve optimum $\mathrm{C} / \mathrm{N}$ 
ratio and also to stabilize the biogas digester. The yield of biogas for pretreated leaves is much higher than non-pretreated leaves. The optimum mixing condition for biogas generation from mixed dried grinded leaves is $6 \%$ leaves and $2 \%$ cow dung. The specific biogas yield for optimum mixing condition is $0.0199 \mathrm{l} / \mathrm{g}$ where the methane content is $69.3 \%$. The percentage of VS and COD reduction is 35.33 and 35.89 respectively. The anaerobic digestion of fallen dried leaves in forest area can be used for biogas generation. The generation of biogas from leaves will benefit us in three ways: clean fuel, nutrient rich biofertilizer and hygienic environment.

\section{References}

APHA, AWWA and WEF (1992), Standard Methods for the Examination of Water \& Wastewater (18 ${ }^{\text {th }}$ ed.), American Public Health Assn., Washington DC.

Birnin-Yauri AU, Muhammad UK, Magaj B (2013), Biomethane generation from the leaves and stems of Ricinus communis under anaerobic condition, International Journal of Environment and Bioenergy, 8(2): 94-101

Eze JI (1995), Studies on generation of biogas from poultry droppings and rice husk from a locally fabricated biodigester. M.Sc. dissertation, University of Nigeria, Nsukka, 64-65.

Fulford D (1998), Running a Biogas Programme, A hand book. "How Biogas Works". Intermediate Technol Publication, London, pp. 33-34.

Goel B, Pant DC and Kishore VVN (2001), Two-phase anaerobic digestion of spent tea leaves for biogas and manure generation, Bioresource Technol, 80(2): 153-156

Garba B, Zuru AA and Sambo AS (1996), Effect of slurry concentration on biogas production from cattle dung, Niger. J. Renewable Energy. 4(2): 38-43.

Hashimoto AG, Chen YR and Varel VH (1980), Theoretical aspects of methane production: State of-the-Art. In proceedings "Livestock waste: A renewable resource". 4th International Symposium on Livestock Wastes. ASAE. 86-91.

Itodo IN and Kucha EI (1998), An empirical relationship for predicting biogas yield from poultry waste slurry, Niger. J. Renewable Energy. Vol. 1\&2: 31-37.

Kozo I, Hisajima S and Darryl RJ (1996), Utilization of agricultural wastes for biogas production in Indonesia, In: Traditional Technology for Environmental
Conservation and Sustainable Development in Asia Pacific Region. 9th Ed. 137-138.

Lucas EB and Bamgboye A (1998), Anaerobic digestion of water hyacinth, Niger. J. Renewable Energy, 6(1): 62-66.

Mahnert P, Heiernann M and Linke B (2005), Batch and semi-continuous biogas production from different grass species. Agricultural Engineering International, The CIGRE J., manuscript EE 05010, Vol. VII.

Nwagbo EE, Dioha IJ and Gulma MA (1991), Qualitative investigation of biogas from cow and donkey dungs, Niger. J. Solar Energy. 10: 145-149.

Rahman MH and Muyeed A (2010), "Solid and Hazardous Waste Management", Published by ITN-BUET, Dhaka, Bangladesh, first edition. pp. 179-214

Rouf MA, Bajpai PK and Jotshi CK (1999), "Characterization of press mud from sugar industry and its potential for biogas generation", Proc. CHEMCON-99 (Indian Chemical Engineering Congress), Chandigarh, December 20-23, pap. RMA-158

Rouf MA, Bajpai PK and Jotshi CK (2010), Optimization of biogas generation from press mud in batch reactor, Bangladesh J. Sci. Ind. Res., 45(4): 371-376

Thangamani A, Rajakumar S and Ramanujam RA (2009), Anaerobic co-digestion of hazardous tannery solid waste and primary sludge: biodegradation kinetics and metabolite analysis, Clean Techn. Environ Policy, Springer

Tomas M, Josef P, Lubomir S and Miloslav D (2012), Increase of biogas production from pretreated hay and leaves using wood-rotting fungi, Chemical Papers 66 (7) 649-653 (2012)

Uzodinma EO, Ofoefule AU, Eze JI and Onwuka ND (2007), Biogas production from blends of agro-industrial wastes. Trends Appl. Sci. Res. 2(6): 554-558

Zuru AA, Saidu H, Odum EA and Onuorah OA (1998), A comparative study of biogas production from horse, goat and sheep dungs. Niger. J. Renewable Energy 6 (1\&2): $43-47$.

Received: 4 June 2015; Revised:30 June 2015;

Accepted: 30 June 2015. 